\begin{tabular}{|l|l|l||}
\hline \multicolumn{2}{|c|}{ PublisherInfo } \\
\hline \hline PublisherName & $:$ & BioMed Central \\
\hline \hline PublisherLocation & $:$ & London \\
\hline \hline PublisherImprintName & $:$ & BioMed Central \\
\hline \hline
\end{tabular}

\title{
Inducible lung-specific induction of RANTES
}

\begin{tabular}{|l|l|l||}
\hline \multicolumn{2}{|c||}{ ArticleInfo } \\
\hline \hline ArticleID & $:$ & 1638 \\
\hline \hline ArticleDOI & $:$ & $10.1186 /$ rr-2001-68570 \\
\hline \hline ArticleCitationID & $:$ & 68570 \\
\hline \hline ArticleSequenceNumber & $:$ & 49 \\
\hline \hline ArticleCategory & $:$ & Paper Report \\
\hline \hline ArticleFirstPage & $:$ & 1 \\
\hline \hline ArticleLastPage & $:$ & 3 \\
\hline \hline & & RegistrationDate $: 2001-9-19$ \\
ArticleHistory & $:$ & Received \\
& $:$ 2000-10-12 \\
\hline \hline ArticleCopyright & $:$ & Biomed Central Ltd2001 \\
\hline \hline ArticleGrants & $:$ & \\
\hline \hline ArticleContext & $:$ & 129312211 \\
\hline \hline
\end{tabular}


Kristen Page, ${ }^{\text {Aff1 }}$

Corresponding Affiliation: Aff1

Aff1 The University of Chicago, USA

\section{Keywords}

Chemokine, lung inflammation, RANTES, transgenic mice

\section{Context}

RANTES (regulated upon activation, normal T cell expressed and secreted), a chemokine initially thought to be chemotactic for T cells and monocytes, has also recently been shown to be a potent eosinophil chemoattractant. Various studies have described an upregulation of RANTES mRNA and an increase in RANTES protein levels in asthmatic patients, suggesting an association between RANTES expression and eosinophilia in asthma and allergic disease. The purpose of this study was to examine the effect of human RANTES (hRANTES) overexpression in mice lungs and determine the effects on leukocyte infiltration and induction of various cytokines and/or chemokines.

\section{Significant findings}

Transgenic mice overexpressing hRANTES in the lung in a doxycycline (Dox)-inducible fashion and their non-transgenic littermates were examined histologically. hRANTES overexpression caused an increase in neutrophils and lymphocytes, but not eosinophils, in bronchoalveolar lavage (BAL) fluid. The authors state that this may be due to the low affinity of hRANTES for murine CCR3, the principal RANTES receptor expressed by eosinophils. In the lungs of the transgenic mice, hRANTES overexpression caused an increase in macrophage inflammatory protein (MIP)-2, a potent neutrophil chemoattractant, interferon-?-inducible protein (IP-10) and monocyte chemotactic protein (MCP)-1 mRNAs. The expression of eotaxin, lymphotactin, MIP-1a, MIP-1? or T cell activation gene mRNAs was not induced by RANTES overexpression. Transgenic mice treated with Dox and sensitized with ovalbumin had a higher total cell count in BAL fluid, a significant increase in neutrophils, and a slight increase in eosinophils, lymphocytes and macrophages upon antigen challenge than their non-transgenic counterparts. These data suggest that RANTES is a strong stimulus for recruitment of neutrophils in the lung. 


\section{Comments}

This study stongly suggests that overexpression of RANTES promotes recruitment of neutrophils in the lung. This is most likely due to the increase in expression of the chemokine, MIP-2, although the contributions of other chemokines such as IP-10 and MCP-1 in neutrophil recruitment cannot be ruled out. Increased RANTES expression, which can be seen in respiratory viral infections, may, therefore, play a role in the associated neutrophilia and exacerbations of asthma.

\section{Methods}

Transgenic mice, northern blot, RNase protection assay, ELISA

\section{Additional information}

\section{References}

1. Pan Z-Z, Parkyn L, Ray A, Ray P: Inducible lung-specific expression of RANTES: preferential recruitment of neutrophils. Am J Physiol Lung Cell Mol Physiol. 2000, 279: 658-666.

This PDF file was created after publication. 